\title{
The Association Between Fluoroquinolones and Aortic Dissection and Aortic Aneurysms: A Systematic Review and Meta-Analysis
}

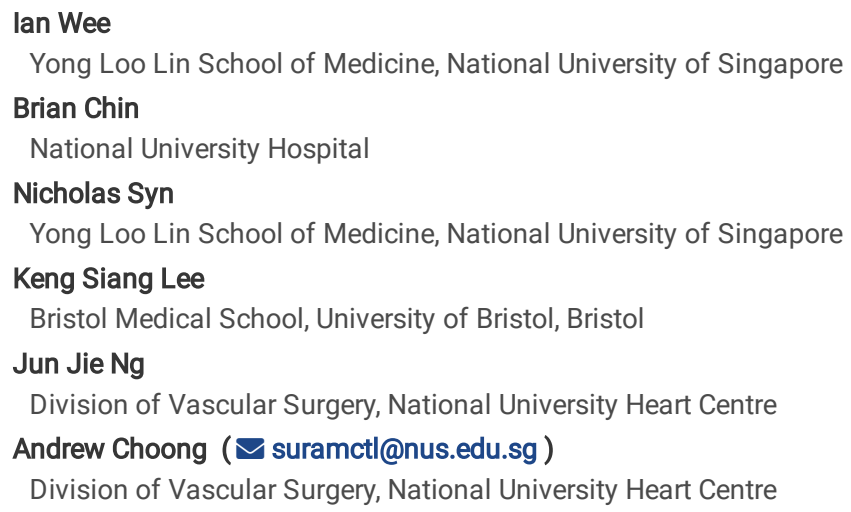




\section{Abstract}

Previous studies have drawn causal associations between fluoroquinolone use and collagen pathologies including tendon rupture and retinopathy. This metaanalysis attempted to assess the association between fluoroquinolone use and the risk of aortic dissection or aortic aneurysm. A systematic search was performed on Medline, EMBASE, and the Cochrane library. 9 studies were included in final analysis. Primary random-effects meta-analysis of 7 studies, excluding 2 pharmacovigilance studies demonstrated statistically increased odds of aortic dissection (OR, 2.38; $95 \%$ Cl, 1.71 - 3.32) aortic aneurysm (OR, $1.98 ; 95 \% \mathrm{Cl}, 1.59-2.48)$, and aortic aneurysm or dissection ( $\mathrm{OR}, 1.47 ; 95 \% \mathrm{Cl}, 1.13-1.89 ; 12=72 \%$ ) with current use of fluoroquinolones compared to their nonuser counterparts. Based on the "number needed-to-harm" analysis, 7246 (95\% Cl: 4329 to 14085) patients would need to be treated with fluoroquinolones for a duration of at least three days in order for one additional patient to be harmed, assuming a population baseline incidence of aortic dissection and aneurysm rupture to be 10 per 100,000 patient-years. With strong statistical association, these findings suggest a causal relationship, warranting future research to elucidate the pathophysiological and mechanistic plausibility of this association. These findings however, should not cease prescription of fluoroquinolones, especially when clinically indicated.

\section{Introduction}

Fluoroquinolones rank amongst the top most frequently used antibiotics ${ }^{1-3}$. Epidemiological studies have shown an increased risk of tendon disorders associated with fluoroquinolone use, such as tendinopathy and Achilles tendon rupture ${ }^{4-6}$. In vitro studies have demonstrated the mechanistic associations attesting the properties of these antibiotic involved in potentiating the activity of matrix metalloproteinases, resulting in degradation of collagen and structural components of the extracellular matrix. This is accompanied by features of oxidative stress in tendon cells, and reduction of collagen production ${ }^{7-10}$.

Collagen constitutes a major extracellular matrix component of the aortic wall, particularly of variants type I and III ${ }^{11}$, raising the concern that fluoroquinolones may increase the risk of the formation of aortic aneurysms and dissections particularly given that these aortic pathologies are associated with changes in collagen structure and content ${ }^{12}$.

The incidence of aortic dissections and aneurysms are also increasing, potentially conferring profound life-threatening consequences to patients if left untreated ${ }^{13-18}$. Given the widespread use of fluoroquinolones, any plausible drug-related risk of aortic aneurysms and dissections should be investigated thoroughly. The main objective of this present study was to appraise real-world evidence of the association between fluoroquinolone and the occurrence of aortic dissections or aneurysms.

\section{Results}

The systematic search revealed 159 unique titles, 2 additional articles were manually sourced from reference lists. 18 were included after title and abstract screening, and reviewed in their entirety. Nine were excluded due to various reasons as shown in Fig. 1 (colored), leaving 9 studies in the final analysis. The risk of bias assessments can be found in Tables 3 and 4 .

\section{Study Design}

Characteristics of all 9 studies are shown in Table 1. Daneman et al's population-based longitudinal cohort study incepted 1.7 million elderly participants (aged above 65 years old) from the Ontario Registered Persons Database between 1997-2012, with a total follow-up duration of 22380515 patient-days on treatment. Lee et al's propensity-matched population-based nested case control study included 1477 cases and 147700 matched controls (based on age, sex, index date) from the National Health Insurance Research Database in Taiwan. Pasternak et al's propensity-matched population-based cohort study incepted a cohort of 360088 patients (aged above 50 years old) with fluoroquinolone use from linked nationwide data from Swedish registers 2006-2013, subsequently compared with another 360088 propensity score-matched comparator episodes of Amoxicillin use. All 9 studies evaluated different types of fluoroquinolones, with Taiwan studies by Dong et al. and Lee et al. evaluating additional fluoroquinolones unavailable in North America. In addition, both Daneman and Lee et al's studies had multivariable adjustment for demographic cardiovascular and healthcare use including indications for fluoroquinolone usage and comorbidity score. 
Table 1

Study design of included studies

\begin{tabular}{|c|c|c|c|c|c|c|c|}
\hline Study Authors & Study Design & Country & $\begin{array}{l}\text { Follow-up } \\
\text { Duration }\end{array}$ & Participants & Interventions & Selection Criteria & Controls \\
\hline Daneman et al & $\begin{array}{l}\text { Population-based } \\
\text { longitudinal cohort } \\
\text { study }\end{array}$ & Ontario & $\begin{array}{l}\text { Patient-days on } \\
\text { treatment: } \\
22380515\end{array}$ & $\begin{array}{l}\text { Inception } \\
\text { cohort of > } \\
65 y \text { from } \\
\text { Ontario } \\
\text { Registered } \\
\text { Persons } \\
\text { Database } \\
\text { 1997-2012 }\end{array}$ & $\begin{array}{l}\text { Ciprofloxacin, } \\
\text { levofloxacin, ofloxacin, } \\
\text { norfloxacin, } \\
\text { moxifloxacin in } \\
\text { outpatient setting }\end{array}$ & $\begin{array}{l}\text { AA and } \\
\text { AD using } \\
\text { administrative } \\
\text { codes }\end{array}$ & $\begin{array}{l}\text { Positive and } \\
\text { Negative } \\
\text { Tracer } \\
\text { Exposure }\end{array}$ \\
\hline Dong et al & $\begin{array}{l}\text { Population-based } \\
\text { nested case } \\
\text { control }\end{array}$ & Taiwan & $\begin{array}{l}\text { Mean Follow-up } \\
\text { Duration: } 1303.82 \\
\text { [723.12] days }\end{array}$ & $\begin{array}{l}\text { Adult patients } \\
\text { from the } \\
\text { Taiwan } \\
\text { population- } \\
\text { based health } \\
\text { insurance } \\
\text { claims } \\
\text { database from } \\
2009-2015 \text {. }\end{array}$ & Fluoroquinolones & $\begin{array}{l}\text { Cases of first AA } \\
\text { and } \\
\text { AD requiring } \\
\text { hospitalization } \\
\text { using the ICD-9- } \\
\text { CM code } 441 \text { in } \\
\text { any diagnosis } \\
\text { position for the } \\
\text { cases }\end{array}$ & $\begin{array}{l}\text { Each } \\
\text { incident } \\
\text { case of } \\
\text { AA/AD was } \\
\text { matched } \\
\text { with } 10 \\
\text { control } \\
\text { individuals } \\
\text { by age, sex, } \\
\text { and follow- } \\
\text { up duration } \\
\text { in the } \\
\text { database } \\
\text { using risk- } \\
\text { set } \\
\text { sampling. }\end{array}$ \\
\hline $\begin{array}{l}\text { Gopalakrishnan } \\
\text { et al }\end{array}$ & $\begin{array}{l}\text { Propensity- } \\
\text { matched } \\
\text { population-based } \\
\text { cohort study }\end{array}$ & $\begin{array}{l}\text { United } \\
\text { States }\end{array}$ & 60 days & $\begin{array}{l}\text { Adult patients } \\
\text { from United } \\
\text { States } \\
\text { commercial } \\
\text { health } \\
\text { insurance } \\
\text { claims } \\
\text { database from } \\
2003-2015\end{array}$ & $\begin{array}{l}\text { Ciprofloxacin, } \\
\text { levofloxacin }\end{array}$ & $\begin{array}{l}139772 \text { treatment } \\
\text { episodes of } \\
\text { fluoroquinolone } \\
\text { use }\end{array}$ & $\begin{array}{l}139722 \\
\text { propensity } \\
\text { score- } \\
\text { matched } \\
\text { comparator } \\
\text { episodes } \\
\text { azithromycin } \\
\text { use }\end{array}$ \\
\hline Lee at al & $\begin{array}{l}\text { Propensity- } \\
\text { matched } \\
\text { population-based } \\
\text { nested case } \\
\text { control }\end{array}$ & Taiwan & $\begin{array}{l}\text { Mean Follow-up } \\
\text { Duration: } 3613.3\end{array}$ & $\begin{array}{l}\text { Adults from } \\
\text { the Taiwan } \\
\text { National } \\
\text { Health } \\
\text { Insurance } \\
\text { Research } \\
\text { Database } \\
\text { 1998-2011 }\end{array}$ & $\begin{array}{l}\text { Ciprofloxacin, } \\
\text { levofloxacin, ofloxacin, } \\
\text { sparfloxacin, } \\
\text { norfloxacin, } \\
\text { lomefloxacin, } \\
\text { moxifloxacin, } \\
\text { gemifloxacin, } \\
\text { exoxacin, } \\
\text { pefloxacin }\end{array}$ & $\begin{array}{l}1477 \text { cases of } \\
\text { first } A A \text { or } A D \\
\text { requiring } \\
\text { hospitalization } \\
\text { plus imaging with } \\
\text { echocardiography, } \\
\text { magnetic } \\
\text { resonance } \\
\text { imaging, or } \\
\text { angiography }\end{array}$ & $\begin{array}{l}147700 \\
\text { matched } \\
\text { control } \\
\text { cases }\end{array}$ \\
\hline Lee at al & $\begin{array}{l}\text { Case-crossover } \\
\text { study }\end{array}$ & Taiwan & 60 days & $\begin{array}{l}\text { Adults from } \\
\text { the Taiwan } \\
\text { National } \\
\text { Health } \\
\text { Insurance } \\
\text { Research } \\
\text { Database } \\
\text { 2001-2011 }\end{array}$ & $\begin{array}{l}\text { Ciprofloxacin, } \\
\text { levofloxacin, ofloxacin, } \\
\text { sparfloxacin, } \\
\text { norfloxacin, } \\
\text { lomefloxacin, } \\
\text { moxifloxacin, } \\
\text { gemifloxacin, } \\
\text { exoxacin, } \\
\text { pefloxacin }\end{array}$ & $\begin{array}{l}1213 \text { cases of } \\
\text { first } A A \text { or } A D \\
\text { requiring } \\
\text { hospitalization } \\
\text { plus imaging with } \\
\text { echocardiography, } \\
\text { magnetic } \\
\text { resonance } \\
\text { imaging, or } \\
\text { angiography }\end{array}$ & $\begin{array}{l}\text { Participants } \\
\text { acted as } \\
\text { their own } \\
\text { control }\end{array}$ \\
\hline $\begin{array}{l}\text { Maumus- } \\
\text { Robert et al }\end{array}$ & $\begin{array}{l}\text { Case-time control- } \\
\text { study }\end{array}$ & France & 180 days & $\begin{array}{l}\text { Adult patients } \\
\text { from the } \\
\text { French health } \\
\text { insurance } \\
\text { nationwide } \\
\text { databases } \\
\text { from } 2010- \\
2015\end{array}$ & Fluoroquinolones & $\begin{array}{l}\text { Incident aortoiliac } \\
\text { aneurysm or } \\
\text { dissection who } \\
\text { were diagnosed } \\
\text { between 2010- } \\
2015 \text { on } \\
\text { fluoroquinolones }\end{array}$ & $\begin{array}{l}\text { Those on } \\
\text { amoxicillin }\end{array}$ \\
\hline
\end{tabular}




\begin{tabular}{|c|c|c|c|c|c|c|c|}
\hline Study Authors & Study Design & Country & $\begin{array}{l}\text { Follow-up } \\
\text { Duration }\end{array}$ & Participants & Interventions & Selection Criteria & Controls \\
\hline Pasternak et al & $\begin{array}{l}\text { Propensity- } \\
\text { matched } \\
\text { population-based } \\
\text { cohort study }\end{array}$ & Sweden & $\begin{array}{l}\text { Patients } \\
\text { contributed } \\
\text { person time from } \\
\text { the date a } \\
\text { prescription was } \\
\text { filled, to the date } \\
\text { of an outcome } \\
\text { event, end of } \\
\text { follow-up ( } 120 \\
\text { days), end of } \\
\text { study period, } \\
\text { hospital } \\
\text { admission, death, } \\
\text { or new } \\
\text { prescription for a } \\
\text { study antibiotic }\end{array}$ & $\begin{array}{l}\text { Inception } \\
\text { cohort of > } \\
50 y \text { from } \\
\text { linked } \\
\text { nationwide } \\
\text { data from } \\
\text { Swedish } \\
\text { registers } \\
2006-2013\end{array}$ & $\begin{array}{l}\text { Ciprofloxacin, } \\
\text { norfloxacin, and other } \\
\text { fluoroquinolones }\end{array}$ & $\begin{array}{l}360088 \\
\text { treatment } \\
\text { episodes of } \\
\text { fluoroquinolone } \\
\text { use }\end{array}$ & $\begin{array}{l}360088 \\
\text { Propensity } \\
\text { score- } \\
\text { matched } \\
\text { comparator } \\
\text { episodes of } \\
\text { Amoxicillin } \\
\text { use }\end{array}$ \\
\hline Meng et al & $\begin{array}{l}\text { Pharmacovigilance } \\
\text { study }\end{array}$ & China & & $\begin{array}{l}\text { Adult patients } \\
\text { from the US } \\
\text { Food and } \\
\text { Drug } \\
\text { Administration } \\
\text { Adverse Event } \\
\text { Reporting } \\
\text { System } \\
\text { (FAERS) } \\
\text { 2004-2016 }\end{array}$ & $\begin{array}{l}\text { Ciprofloxacin, } \\
\text { levofloxacin and } \\
\text { moxifloxacin }\end{array}$ & $\begin{array}{l}7153801 \text { adverse } \\
\text { event reports: } \\
2713 \text { for aortic } \\
\text { aneurysms and } \\
1008 \text { for aortic } \\
\text { dissections. }\end{array}$ & $\begin{array}{l}\text { Those on } \\
\text { cefuroxime }\end{array}$ \\
\hline Sommet et al & $\begin{array}{l}\text { Pharmacovigilance } \\
\text { study }\end{array}$ & France & & $\begin{array}{l}\text { Patients }>50 y \\
\text { registered on } \\
\text { the Vigibase }{ }^{\circledR}, \\
\text { World Health } \\
\text { Organization } \\
\text { Global } \\
\text { Individual } \\
\text { Case Safety } \\
\text { Reports } \\
\text { (ICSRs) } \\
\text { database from } \\
1972 \text { to } 2017\end{array}$ & $\begin{array}{l}\text { Levofloxacin, } \\
\text { Ciprofloxacin, } \\
\text { Moxifloxacin, } \\
\text { Ofloxacin, } \\
\text { Gatifloxacin, } \\
\text { Tosufloxacin, } \\
\text { Enoxacin, Fleroxacin, } \\
\text { Gemifloxacin, } \\
\text { Grepafloxacin, } \\
\text { Lomefloxacin, } \\
\text { Norfloxacin, } \\
\text { Pazufloxacin, } \\
\text { Pefloxacin, } \\
\text { Prulifloxacin, } \\
\text { Rufloxacin, } \\
\text { Sparfloxacin, } \\
\text { Temafloxacin, } \\
\text { Trovafloxacin }\end{array}$ & $\begin{array}{l}172,588 \text { were } \\
\text { reported with } \\
\text { fluoroquinolones }\end{array}$ & $\begin{array}{l}40,658 \text { with } \\
\text { amoxicillin }\end{array}$ \\
\hline
\end{tabular}

\section{Exposure}

Fluoroquinolone exposure was defined differently in most studies according to various prescription databases. For instance, Daneman's cohort study defined exposure risk as up to 30 days after fluoroquinolone use. Lee's case control study categorised exposures into current fluoroquinolone exposure within 60 days of index date, recent exposure within 60-365 days before index date, and any exposure for 3 or more days in the 1-year period before index date. Pasternak's cohort study defined exposure to fluoroquinolones as a 60-day period from start of treatment, with secondary analysis investigating subsequent 60 days (days 61-120). Further subdivision of the 60-day risk period into 10 day intervals was conducted to assess number of events per interval.

\section{Outcome}

3 studies utilised administrative diagnostic codes to identify aortic aneurysms and dissections. The primary outcomes were collagen-associated severe toxicities in Daneman's study, and first occurrence of aortic aneurysm or dissection in inpatients in both Lee's and Pasternak's study.

\section{Primary Meta-Analysis}

Random-effects meta-analysis of 4 studies reflected that current use of fluoroquinolones was associated with a statistically significant increased odds of aortic dissection (OR, 2.38; $\left.95 \% \mathrm{Cl}, 1.71-3.32 ; \mathrm{I}^{2}=48 \%\right)$. Meta-analysis of another 4 studies reflected that current use of fluoroquinolones was associated with a statistically significant increased odds of aortic aneurysm (OR, 1.98; $\left.95 \% \mathrm{Cl}, 1.59-2.48 ; \mathrm{I}^{2}=77 \%\right)$. Finally, meta-analysis of 5 studies showed a significantly increased odds of aortic dissection or aneurysm (OR, 1.47; $\left.95 \% \mathrm{Cl}, 1.13-1.89 ; \mathrm{I}^{2}=72 \%\right)$ with current use of fluoroquinolones compared to their nonuser counterparts (Figs. 2, 3 and 4 - colored). The results of this primary analysis excluded the 2 pharmacovigilance studies and is considered more robust, because of greater similarity between the cohort \& case-control studies as compared to the pharmacovigilance studies (the patient populations of the pharmacovigilance database represent a selected population of patients who were reported to the FDA for experiencing an adverse drug event).

\section{Sensitivity Analysis}

A sensitivity analysis was performed by including the full list of included studies including the pharmacovigilance studies. Random-effects meta-analysis of 5 studies reflected that current use of fluoroquinolones was associated with statistically significant increased odds of aortic dissection (OR, 2.30; $95 \% \mathrm{Cl}, 1.67-$ $3.17 ; I^{2}=42 \%$ ). Meta-analysis of another 5 studies reflected that current use of fluoroquinolones was associated with statistically significant increased odds of 
aortic aneurysm (OR, 2.00; $\left.95 \% \mathrm{Cl}, 1.63-2.45 ; \mathrm{I}^{2}=70 \%\right)$. Finally, meta-analysis of 7 studies showed a significantly increased odds of aortic dissection or aneurysm (OR, 1.65; 95\% Cl, 1.26-2.14; $\mathrm{I}^{2}=78 \%$ ) with current use of fluoroquinolones compared to their nonuser counterparts (Figs. 2,3 and 4 ).

\section{Hazard Ratios for Past Exposure}

Lee et al's study was the sole study which compared risks of aortic aneurysm and dissection between individuals with past exposure/any prior users of fluoroquinolones, and nonusers. Propensity score-matched estimates for past exposure (incidence rate ratio, $1.19 ; 95 \% \mathrm{Cl}, 0.85-1.66$ ) and any prior users (incidence rate ratio, $1.37 ; 95 \% \mathrm{Cl}, 1.04-1.79$ ), as well as covariate adjusted estimates for past exposure (incidence rate ratio, $1.49 ; 95 \% \mathrm{Cl}, 1.18-1.90$ ) and any prior users (incidence rate ratio, $1.69 ; 95 \% \mathrm{Cl}, 1.39-2.06$ ) were found to be statistically significant.

\section{Number Needed to Harm for Aortic Dissection or Aneurysm with or without Rupture}

The number needed to treat to harm for the various aortic pathologies is summarised in Table 2. A range of estimates regarding baseline incidence are provided below for ease of reference to clinicians, who should tailor their decisions accordingly. For example, assuming that the population baseline incidence of aortic dissection and aneurysm rupture was 10 per 100,000 patient-years, then 7246 ( $95 \%$ Cl: 4329 to 14085) patients would need to be treated with fluoroquinolones for a duration of at least three days in order for one additional patient to be harmed. Even if we assumed the baseline rate of aortic dissection and aneurysm rupture to be higher at 150 events per 100,000 patient year (e.g., in high-risk patient populations such as elderly males), the number needed to harm is 483 (95\% Cl: 289 to 939) (Table 2). 
Table 2

Number needed to treat to harm for aortic pathologies

\begin{tabular}{|c|c|c|}
\hline $\begin{array}{l}\text { Aortic pathology } \\
\text { (assumed rate } \\
\text { ratio) }\end{array}$ & $\begin{array}{l}\text { Assumed baseline incidence of aortic pathology (number of events per } 100,000 \text { patient years) } \\
\text { Note: baseline incidence may vary across geography, gender, age, and other clinical characteristics. A range of } \\
\text { estimates regarding baseline incidence are provided below for ease of reference to clinicians, who should tailor } \\
\text { their decisions accordingly }\end{array}$ & $\begin{array}{l}\text { Number needed } \\
\text { to harm }(\mathrm{NNH}) \\
(95 \% \mathrm{Cl})\end{array}$ \\
\hline \multirow{10}{*}{$\begin{array}{l}\text { Aortic dissection } \\
\text { or aneurysm } \\
\text { rupture } \\
\text { (Pooled rate ratio: } \\
2.38 \text { [95\% Cl } 1.71 \\
\text { to } 3.32] \text { ) }\end{array}$} & 3 & $\begin{array}{l}24155 \text { (95\% Cl: } \\
14430 \text { to } \\
46948)\end{array}$ \\
\hline & 5 & $\begin{array}{l}14493(95 \% \mathrm{Cl}: \\
8658 \text { to } 28169)\end{array}$ \\
\hline & 10 & $\begin{array}{l}7246 \text { (95\% Cl: } \\
4329 \text { to } 14085)\end{array}$ \\
\hline & 15 & $\begin{array}{l}4831 \text { (95\% Cl: } \\
2886 \text { to } 9390)\end{array}$ \\
\hline & 25 & $\begin{array}{l}2899(95 \% \mathrm{Cl}: \\
1732 \text { to } 5634)\end{array}$ \\
\hline & 50 & $\begin{array}{l}1449 \text { (95\% Cl: } \\
866 \text { to } 2817 \text { ) }\end{array}$ \\
\hline & 75 & $\begin{array}{l}966 \text { (95\% Cl: } \\
577 \text { to } 1878)\end{array}$ \\
\hline & 100 & $\begin{array}{l}725 \text { (95\% Cl: } \\
433 \text { to } 1408)\end{array}$ \\
\hline & 125 & $\begin{array}{l}580 \text { (95\% Cl: } \\
346 \text { to } 1127)\end{array}$ \\
\hline & 150 & $\begin{array}{l}483 \text { (95\% Cl: } \\
289 \text { to } 939)\end{array}$ \\
\hline \multirow{9}{*}{$\begin{array}{l}\text { Aortic aneurysm } \\
\text { (Pooled rate ratio: } \\
1.98[95 \% \mathrm{Cl} 1.59 \\
\text { to } 2.48] \text { ) }\end{array}$} & 5 & $\begin{array}{l}20408 \text { (95\% Cl: } \\
13514 \text { to } \\
33898)\end{array}$ \\
\hline & 25 & $\begin{array}{l}4082(95 \% \mathrm{Cl}: \\
2703 \text { to } 6780)\end{array}$ \\
\hline & 50 & $\begin{array}{l}2041 \text { (95\% Cl: } \\
1351 \text { to } 3390)\end{array}$ \\
\hline & 75 & $\begin{array}{l}1361 \text { (95\% Cl: } \\
901 \text { to } 2260)\end{array}$ \\
\hline & 100 & $\begin{array}{l}1020 \text { (95\% Cl: } \\
676 \text { to } 1695)\end{array}$ \\
\hline & 125 & $\begin{array}{l}816(95 \% \mathrm{Cl}: \\
541 \text { to } 1356)\end{array}$ \\
\hline & 150 & $\begin{array}{l}680 \text { (95\% Cl: } \\
450 \text { to } 1130)\end{array}$ \\
\hline & 250 & $\begin{array}{l}408 \text { (95\% Cl: } \\
270 \text { to } 678)\end{array}$ \\
\hline & 300 & $\begin{array}{l}340 \text { (95\% Cl: } \\
225 \text { to } 565)\end{array}$ \\
\hline
\end{tabular}

\section{Risk of bias and publication bias}

The risk of bias was assessed using the Newcastle-Ottawa scale. Overall, the risk of selection and exposure bias were low. However, the overall comparability was deemed to be inadequate because the studies failed to control for all important risk factors of aortic aneurysm and dissection, particularly smoking. The assessment of publication bias was not meaningful due to the small number of studies, and hence was not performed. Results of the assessments can be found in Tables 3 and 4. 
Table 3

Risk of bias assessment for case-control studies

\begin{tabular}{|c|c|c|c|c|c|c|c|c|c|}
\hline \multirow{2}{*}{$\begin{array}{l}\text { First } \\
\text { author, } \\
\text { year }\end{array}$} & \multicolumn{4}{|l|}{ Selection } & \multirow{2}{*}{$\begin{array}{l}\text { Comparability } \\
\text { Comparability of } \\
\text { Cases and Controls } \\
\text { on the Basis of the } \\
\text { Design or Analysis }\end{array}$} & \multicolumn{3}{|l|}{ Exposure } & \multirow{2}{*}{$\begin{array}{l}\text { Total } \\
\text { points } \\
\text { (/9) }\end{array}$} \\
\hline & $\begin{array}{l}\text { Adequate } \\
\text { case } \\
\text { definition }\end{array}$ & $\begin{array}{l}\text { Representativeness } \\
\text { of the cases }\end{array}$ & $\begin{array}{l}\text { Control } \\
\text { selection }\end{array}$ & $\begin{array}{l}\text { Definition } \\
\text { of } \\
\text { controls }\end{array}$ & & $\begin{array}{l}\text { Ascertainment } \\
\text { of exposure }\end{array}$ & $\begin{array}{l}\text { Non- } \\
\text { response } \\
\text { rate }\end{array}$ & $\begin{array}{l}\text { Similar } \\
\text { method of } \\
\text { ascertainment } \\
\text { for cases and } \\
\text { control }\end{array}$ & \\
\hline $\begin{array}{l}\text { Dong } \\
2020\end{array}$ & Yes & Yes & $\begin{array}{l}\text { Community } \\
\text { controls }\end{array}$ & $\begin{array}{l}\text { No } \\
\text { history of } \\
\text { disease }\end{array}$ & $\begin{array}{l}\text { Study controls for } \\
\text { risk factors for } \\
\text { aortic aneurysm } \\
\text { but lacks other } \\
\text { important risk } \\
\text { factors (smoking) }\end{array}$ & $\begin{array}{l}\text { Medical } \\
\text { records }\end{array}$ & N.A & Yes & $7 / 9$ \\
\hline Lee2015 & Yes & Yes & $\begin{array}{l}\text { Community } \\
\text { controls }\end{array}$ & $\begin{array}{l}\text { No } \\
\text { history of } \\
\text { disease }\end{array}$ & $\begin{array}{l}\text { Study controls for } \\
\text { risk factors for } \\
\text { aortic aneurysm } \\
\text { but lacks other } \\
\text { important risk } \\
\text { factors (smoking) }\end{array}$ & $\begin{array}{l}\text { Medical } \\
\text { records }\end{array}$ & N.A & Yes & $7 / 9$ \\
\hline Lee2018 & Yes & Yes & $\begin{array}{l}\text { Community } \\
\text { controls }\end{array}$ & $\begin{array}{l}\text { No } \\
\text { history of } \\
\text { disease }\end{array}$ & $\begin{array}{l}\text { Study controls for } \\
\text { risk factors for } \\
\text { aortic aneurysm } \\
\text { but lacks other } \\
\text { important risk } \\
\text { factors (smoking) }\end{array}$ & $\begin{array}{l}\text { Medical } \\
\text { records }\end{array}$ & N.A & Yes & $7 / 9$ \\
\hline $\begin{array}{l}\text { Maumus- } \\
\text { Robert } \\
2019\end{array}$ & Yes & Yes & $\begin{array}{l}\text { Community } \\
\text { controls }\end{array}$ & $\begin{array}{l}\text { No } \\
\text { history of } \\
\text { disease }\end{array}$ & $\begin{array}{l}\text { Study controls for } \\
\text { risk factors for } \\
\text { aortic aneurysm } \\
\text { but lacks other } \\
\text { important risk } \\
\text { factors (smoking) }\end{array}$ & $\begin{array}{l}\text { Medical } \\
\text { records }\end{array}$ & N.A & Yes & $7 / 9$ \\
\hline
\end{tabular}

Table 4

Risk of bias assessment for cohort studies

\begin{tabular}{|c|c|c|c|c|c|c|c|c|c|}
\hline \multirow[t]{2}{*}{ First author, year } & \multicolumn{4}{|l|}{ Selection } & \multirow{2}{*}{$\begin{array}{l}\text { Comparability } \\
\text { Comparability } \\
\text { of Cohorts on } \\
\text { the Basis of } \\
\text { the Design or } \\
\text { Analysis }\end{array}$} & \multicolumn{3}{|l|}{ Outcome } & 1 \\
\hline & $\begin{array}{l}\text { Representativeness } \\
\text { of exposed cohort }\end{array}$ & $\begin{array}{l}\text { Selection } \\
\text { of non- } \\
\text { exposed } \\
\text { cohort }\end{array}$ & $\begin{array}{l}\text { Ascertainment } \\
\text { of exposure }\end{array}$ & $\begin{array}{l}\text { Demonstration } \\
\text { that outcome } \\
\text { of interest was } \\
\text { absent at start } \\
\text { of study }\end{array}$ & & $\begin{array}{l}\text { Assessment } \\
\text { of Outcome }\end{array}$ & $\begin{array}{l}\text { Length } \\
\text { of follow- } \\
\text { up }\end{array}$ & $\begin{array}{l}\text { Adequacy } \\
\text { of follow } \\
\text { up of } \\
\text { cohorts }\end{array}$ & \\
\hline Daneman2015 & $\begin{array}{l}\text { Elderly aged } \\
65 \text { years old and } \\
\text { above }\end{array}$ & $\begin{array}{l}\text { Same } \\
\text { source } \\
\text { as } \\
\text { exposed } \\
\text { cohort }\end{array}$ & $\begin{array}{l}\text { Ontario } \\
\text { database }\end{array}$ & Adequate & $\begin{array}{l}\text { Inadequate } \\
\text { (did not } \\
\text { control for } \\
\text { other } \\
\text { important risk } \\
\text { factors for } \\
\text { aortic } \\
\text { aneurysm } \\
\text { and aortic } \\
\text { dissection) }\end{array}$ & $\begin{array}{l}\text { Record } \\
\text { linkage }\end{array}$ & Adequate & Complete & 7 \\
\hline Gopalakrishnan2020 & $\begin{array}{l}\text { Patients aged } \\
50 \text { years old and } \\
\text { above }\end{array}$ & $\begin{array}{l}\text { Same } \\
\text { sources } \\
\text { as } \\
\text { exposed } \\
\text { cohort }\end{array}$ & $\begin{array}{l}\text { United States } \\
\text { database }\end{array}$ & ?Adequate & $\begin{array}{l}\text { Inadequate } \\
\text { (did not } \\
\text { control for } \\
\text { other } \\
\text { important risk } \\
\text { factors for } \\
\text { aortic } \\
\text { aneurysm } \\
\text { and aortic } \\
\text { dissection) }\end{array}$ & $\begin{array}{l}\text { Record } \\
\text { linkage }\end{array}$ & Adequate & Complete & ; \\
\hline Pasternak2018 & Representative & $\begin{array}{l}\text { Same } \\
\text { sources } \\
\text { as } \\
\text { exposed } \\
\text { cohort }\end{array}$ & $\begin{array}{l}\text { Swedish } \\
\text { registers }\end{array}$ & Adequate & $\begin{array}{l}\text { Inadequate } \\
\text { (did not } \\
\text { control for } \\
\text { other } \\
\text { important risk } \\
\text { factors for } \\
\text { aortic } \\
\text { aneurysm } \\
\text { and aortic } \\
\text { dissection) }\end{array}$ & $\begin{array}{l}\text { Record } \\
\text { linkage }\end{array}$ & Adequate & Complete & 7 \\
\hline
\end{tabular}

\section{Discussion}


There is moderate evidence from this meta-analysis demonstrating the heightened risk of aortic aneurysm or aortic dissection in patients treated with fluoroquinolones. We believe, to our knowledge, this to be the first meta-analysis including the highest number of studies analyzing this relationship. Furthermore, we have performed additional analysis to comprehensively generate the numbers needed to harm based on a wide spectrum of assumed population baseline incidences of aortic aneurysms and dissections.

These findings may be supported by biological plausibility, where fluoroquinolones have been shown to induce epigenetic changes, and augment collagen maturation ${ }^{19}$. Chief of all molecular players is matrix metalloproteinases (MMPs), where its dysregulation propagates extracellular matrix degeneration ${ }^{20-22}$. Cellular studies of smooth muscle cells derived from aortic aneurysms demonstrate an increased expression of MMP-9 and MMP-2 ${ }^{23}$, both of which potentiate collagenolytic activity ${ }^{24,25}$. These corroborated with animal studies showing an increased expression of MMP-9 and MMP-2 in cornea tissue ${ }^{26}$ and MMP-2 in tendon tissue ${ }^{27}$ upon administration of ciprofloxacin. Hence, the destruction of collagen and connective tissue by fluoroquinolones in the aortic wall might portend the development of aortic aneurysm and dissection.

An important temporal aspect of our findings is the timing of this association, where the risk of aortic dissection and aortic aneurysm was increased with current use of fluoroquinolones. Two studies defined this as 60 days after start of treatment ${ }^{28,29}$; one study defined it as 30 days after start of treatment ${ }^{30}$. In particular, Pasternak and colleagues ${ }^{29}$ propounded this association to be the most significant in the first 10 days post-treatment, suggesting that this phenomenon might occur acutely during the active treatment phase. Albeit preliminary, this finding is consistent with in vitro studies demonstrating prompt expression of MMPs in tendon cells after ciprofloxacin administration ${ }^{8,27}$. The seemingly acute nature of the risk period is observed in other pathologies. For instance, fluoroquinolone-induced tendon rupture occurred between 2 and 31 days with a median of 7 days ${ }^{31}$. Similarly, the highest risk of fluoroquinoloneassociated retinal detachment was within 5 days of treatment ${ }^{32}$.

However, our findings must be interpreted in the context of known limitations. First, there were no randomized controlled trials in this study. However, it is not entirely true that observational studies have no role in exemplifying a causal association between an exposure and outcome. Moreover, it is unlikely there will ever be a randomized human trial investigating the association between fluoroquinolone exposure and aortic pathology from practical and ethical standpoints. Next, confounding factors are inevitable in any observational study. Although the original studies provided adjusted estimates for a spectrum of possible confounders employing propensity score method, this does not eliminate residual confounders including smoking status and other cardiovascular risk factors. Moreover, two ${ }^{28,30}$ out of three studies only adjusted for a limited number of covariates, hence potentially missing out several other potential confounding factors. In addition, there could be a possibility of protopathic bias, where clinical symptoms of aortic aneurysm and dissection are

misinterpreted as infection, necessitating antibiotics treatment. However, this appears unlikely given the low risk of such misdiagnosis in real-life settings ${ }^{33}$. In addition, there could be a risk of detection bias, as elegantly pointed out by Lee and colleagues ${ }^{28}$. Given the propensity of imaging examinations such as computed tomographic scans ordered during acute infections, this increases the probability of newly diagnosed aortic pathologies. One other methodological flaw consistent in the original studies was the lack of an active comparator. Whilst Pasternak and colleagues ${ }^{29}$ used amoxicillin as an active comparator to limit confounding factors associated with indication (infection), two other studies compared fluoroquinolone use with no use of antibiotics ${ }^{28,30}$.

Although several factors lend support to the stupendous strength of the association, including biological plausibility; consistent epidemiological evidence; and analogous findings from other pathologies, further research is warranted in other populations to establish a firm conclusion. Furthermore, it is unclear whether the association is driven by aortic aneurysm or aortic dissection, although Pasternak and colleagues argued it could be the former ${ }^{29}$. In this light, we propound that this relationship cannot be proven causal given the aforementioned. Nonetheless, clinicians should continue to prescribe fluoroquinolones if clinically indicated, and we are not advocating cessation of their used based on a theoretical risk of aortic dissection or aortic aneurysm development. Further evidence is warranted to accurately elucidate the pathophysiology of how this may occur mechanistically. With strong statistical association, our findings suggest a causal relationship between the use of fluoroquinolone and increased risk of aortic aneurysm and dissection. Further research is needed to corroborate with these current findings. However, given the numbers needed to harm, this should not change the contemporary evidence-based practice on the use of fluoroquinolone.

\section{Methods}

This review was performed in accordance to the Preferred Reporting Items for Systematic Reviews and Meta-Analyses (PRISMA) statement guidelines ${ }^{34}$. The study protocol was registered on the PROSPERO International Prospective Register of Systematic Reviews (registration number CRD42020212150).

\section{Eligibility criteria}

Any randomized or non-randomized study (cohort study; case-control study) that investigated the association between fluoroquinolone use regardless of indication, and risk of aortic dissection and/or aortic aneurysm were included. The controls were limited to unexposed patients or patients receiving other types of antibiotics. The following designs were excluded: case reports/series; non-English; animal studies. Studies that did not report extractable data including odds ratio; relative risk; hazard ratio; or raw data, were excluded. Conference abstracts were considered only if sufficient data was available for meaningful synthesis and analysis.

\section{Outcome measures}

The primary outcomes of interest were development of aortic dissection or aortic aneurysm amongst patients who: 1) have taken fluoroquinolones in the last 1 year; 2) are currently taking fluoroquinolones for active treatment, limited up to 60 days within index date. 


\section{Systematic search}

A systematic search was performed in the following databases: Medline; EMBASE; and the Cochrane library from inception on 30th September 2020. An exhaustive combination of the following 'MeSH' and 'non-MesH' terms were used: aortic dissection; aortic aneurysm; fluoroquinolones; quinolones. The full search strategy is available upon request from IW.

\section{Selection of studies and data extraction}

Three reviewers (IW, BC, KSL) independently screened and assessed the studies for potential inclusion in two stages: 1) title and abstract screen; 2) full-text review of those titles included in the first stage. Data extraction was also performed independently by three reviewers (IW, BC, KSL) using a standardized proforma. The following data were abstracted: study design, demographics, country and dataset, type of fluoroquinolones, indication for fluoroquinolones, selection criteria, controls, unadjusted hazard ratios (HR) or odds ratio (OR), propensity-score adjusted HR, propensity-score matched HR, and covariateadjusted HR. Conflicts were resolved by consensus, or by appeal to a fourth senior author (AC).

For studies with outcomes of interest reported but not specific to fluoroquinolone exposure, the corresponding authors were contacted for acquisition of raw data. A response was anticipated for two weeks before a decision was made on the eligibility of the study

\section{Risk of bias and quality assessment}

The Newcastle-Ottawa Scale for Quality Assessment for cohort and case-control studies was employed to assess the risk of bias of included studies ${ }^{35}$. In brief, the assessment of case-control studies includes 8 domains: 1) adequate case definition; 2) representativeness of cases; 3 ) control selection; 4) definition of controls; 5) comparability of cases and controls on the basis of design or analysis; 6) ascertainment of exposure; 7) non-responses rate; 8) similar method of ascertainment for cases and control. The assessment of cohort studies also includes 8 domains: 1) selection of non-exposed cohort; 2) representativeness of cases; 3 ) ascertainment of exposure; 4) demonstration that outcome of interest was absent at start of study; 5) comparability of cohort on the basis of design or analysis; 6 ) assessment of outcome; 7) length of follow-up; 8) adequacy of follow-up of cohorts. Based on the aforementioned, the studies will be scored against a maximum of 9 points.

\section{Data analysis}

Meta-analyses were done assuming the random effects model to account for both within-study and between-study heterogeneity. The random-effects metaanalysis was employed even when quantitative heterogeneity was low (defined as having an $\mathrm{I}^{2}$ statistic value of less than $50 \%$ ), in order to also account for qualitative heterogeneity which may not have been evident from the $\mathrm{I}^{2}$ value alone. Conditional odds ratios (ORs) (which was the effect measure in these studies) ${ }^{28,36,37}$ were taken to be interchangeable with the hazard ratios since the likelihood functions of the conditional logistic model is mathematically identical to the stratified Cox model when estimated under partial likelihood. The incidence rate ratios and hazard ratios were likewise taken to approximate one another owing to the functional similarities between the Poisson and Weibull regressions, while the relative risk was assumed to approximate the hazard ratio since right-censoring due to loss to follow-up was likely to be minimal because the exposure-time and follow-up duration were short. As such, the main effect measure in our analyses was the incidence rate ratio.

For the study by Meng et al., ${ }^{38}$ we calculated the "cefuroxime-adjusted" reporting odds ratio (ROR) by taking the ratio of the pooled ROR of the three fluoroquinolones divided by the ROR of cefuroxime (the negative control). Notably, this approach is similar to that of the study by Maumus-Robert et al., ${ }^{36}$ which reported an "amoxicillin-adjusted" odds ratios, where Maumus-Robert et al. calculated as the ratio of ORs for fluoroquinolones divided by OR for amoxicillin). The $95 \%$ confidence intervals for the adjusted reporting ORs were calculated assuming a lognormal distribution for the adjusted OR, as follows:

Point estimate of adjusted $\mathrm{ORs}=\mathrm{AOR}=\mathrm{OR}_{\text {fluoroquinolone }} / \mathrm{OR}_{\text {control }}$.

Standard error[OR $\left.\mathrm{OR}_{\text {fluoroquinolone }}\right]=\left(\ln \left(\mathrm{UCL}_{\text {fluoroquinolone }}-\mathrm{LCL}_{\text {fluoroquinolone }}\right) / 1.96\right.$.

Standard error[OR $\left.\mathrm{O}_{\text {control }}\right]=\left(\ln \left(\mathrm{UCL}_{\text {control }}-\mathrm{LCL}_{\text {control }}\right) / 1.96\right.$.

The pooled standard error can be calculated as:

SEpooled $\left.\left.=\operatorname{sqrt}[(\text { Standard error[ORfluoroquinolone }])^{2}+(\text { Standard error[ORcontrol] })^{2}\right)\right]$.

The $95 \%$ confidence intervals of the AOR can then be calculated as: $\exp [\ln ($ AOR $)+/-1.96$ * SEpooled]

For example, the Maumus-Robert study reported an OR of fluoroquinolones of 3.23 (95\% Cl: 1.85 to 5.64 ) and an OR of amoxicillin of 1.32 (95\% Cl: 0.99 to 1.76). ${ }^{36}$ The Maumus-Robert study also reported an amoxicillin-adjusted OR of 2.44 (95\% Cl: 1.31 to 4.57 ). ${ }^{36}$ Using our formula above, we are able to reverseengineer the adjusted OR, obtaining an amoxicillin-adjusted OR of 2.45 ( $95 \% \mathrm{Cl}: 1.31$ to 4.58$)$. Notably, our estimate of the adjusted OR is nearly identical to that of the exact OR provided by Maumus-Robert et al. ${ }^{36}$ Hence, these formulae were likewise applied to the Meng 2019 study to estimate the cefuroximeadjusted OR.

The number needed to treat to harm, and its $95 \% \mathrm{Cl}$ was also assessed to estimate an absolute measure of effect. The number needed to treat to harm is the number of patients who need to be treated with fluoroquinolones for 1 additional patient to have an adverse event. The baseline risk was obtained from the unexposed group in the population-based studies. 


\section{Declarations \\ Contributions}

IW, BC, NS, KSL. Contributions: Methodology, investigation, project administration, validation, writing - original draft, writing - review \& editing, visualization.

JJN and AMTLC. Contributions: Conceptualization, methodology, investigation, project administration, validation, writing - original draft, writing - review \&

editing, visualization, supervision

\section{Acknowledgements}

None

\section{Conflict of interest statement}

All authors report no conflict of interest. All authors do not have any financial and personal relationships with other people or organizations that could inappropriately influence (bias) their work.

\section{Funding}

This study received no financial supported.

\section{Ethical Approval for Research}

Ethical approval was not required for this systematic review and meta-analysis.

\section{Other declarations}

This study has not been presented at any international conferences.

\section{References}

1. Hicks, L. A., Taylor, T. H., Jr. \& Hunkler, R. J. U.S. outpatient antibiotic prescribing, 2010. The New England journal of medicine 368, 1461-1462, doi:10.1056/NEJMc1212055 (2013).

2. Linder, J. A., Huang, E. S., Steinman, M. A., Gonzales, R. \& Stafford, R. S. Fluoroquinolone prescribing in the United States: 1995 to 2002. The American journal of medicine 118, 259-268, doi:10.1016/j.amjmed.2004.09.015 (2005).

3. Zhang, Y., Steinman, M. A. \& Kaplan, C. M. Geographic variation in outpatient antibiotic prescribing among older adults. Archives of internal medicine 172, 1465-1471, doi:10.1001/archinternmed.2012.3717 (2012).

4. van der Linden, P. D., van de Lei, J., Nab, H. W., Knol, A. \& Stricker, B. H. C. Achilles tendinitis associated with fluoroquinolones. British Journal of Clinical Pharmacology 48, 433-437, doi:10.1046/j.1365-2125.1999.00016.x (1999).

5. Wise, B., Peloquin, C., Choi, H., Lane, N. \& Zhang, Y. Impact of Age, Sex, Obesity, and Steroid Use on Quinolone-Associated Tendon Disorders. The American journal of medicine 125, 1228.e1223-1228.e1228, doi:10.1016/j.amjmed.2012.05.027 (2012).

6. Lewis, T. \& Cook, J. Fluoroquinolones and Tendinopathy: A Guide for Athletes and Sports Clinicians and a Systematic Review of the Literature. Journal of Athletic Training 49, 422-427, doi:10.4085/1062-6050-49.2.09 (2014).

7. Tsai WC, Hsu C., Chen CP, et al. Ciprofloxacin up-regulates tendon cells to express matrix metalloproteinase-2 with degradation of type I collagen. $J$ Orthop Res 29 (2011)

8. Corps AN, Harrall R., Curry VA, Fenwick SA, Hazleman BL, Riley GP. Ciprofloxacin enhances the stimulation of matrix metalloproteinase 3 expression by interleukin-1beta in human tendon-derived cells. A potential mechanism of fluoroquinolone-induced tendinopathy.. Arthritis Rheum 46, 3034-3040 (2002).

9. Chang HN, Pang J., Chen CP, et al. The effect of aging on migration, proliferation, and collagen expression of tenocytes in response to ciprofloxacin. $J$ Orthop Res 30, 764-768 (2012).

10. Pouzaud F, B.-Beaubois K., Thevenin M, Warnet JM, Hayem G, Rat P. In vitro discrimination of fluoroquinolones toxicity on tendon cells: involvement of oxidative stress. J Pharmacol Exp Ther 308 (2004).

11. P, B. The role of collagen in the aorta's structure. Open Circulation Vascular J 6, 1-8 (2013).

12. de Figueiredo BL, J. R., Dias RR, et al. Collagen is reduced and disrupted in human aneurysms and dissections of ascending aorta. Human Pathology 39 , 437-443 (2008).

13. Kurz, S. D. et al. Insight into the incidence of acute aortic dissection in the German region of Berlin and Brandenburg. International journal of cardiology 241, 326-329, doi:10.1016/j.ijcard.2017.05.024 (2017). 
14. Olsson, C., Thelin, S., Stahle, E., Ekbom, A. \& Granath, F. Thoracic aortic aneurysm and dissection: increasing prevalence and improved outcomes reported in a nationwide population-based study of more than 14,000 cases from 1987 to 2002. Circulation 114, 2611-2618, doi:10.1161/circulationaha.106.630400 (2006).

15. Clouse, W. D. et al. Acute aortic dissection: population-based incidence compared with degenerative aortic aneurysm rupture. Mayo Clinic proceedings 79, 176-180 (2004).

16. Nienaber, C. A. \& Clough, R. E. Management of acute aortic dissection. Lancet (London, England) 385, 800-811, doi:10.1016/s0140-6736(14)61005-9 (2015).

17. Nienaber, C. A., Divchev, D., Palisch, H., Clough, R. E. \& Richartz, B. Early and late management of type B aortic dissection. Heart 100, 1491-1497 (2014).

18. Tsai, T. T. et al. Long-term survival in patients presenting with type A acute aortic dissection: insights from the International Registry of Acute Aortic Dissection (IRAD). Circulation 114, I350-356, doi:10.1161/circulationaha.105.000497 (2006).

19. Badal, S., Her, Y. F. \& Maher, L. J. Nonantibiotic Effects of Fluoroquinolones in Mammalian Cells. The Journal of Biological Chemistry 290, 22287-22297, doi:10.1074/jbc.M115.671222 (2015).

20. Akiyama, M., Ohtani, H., Sato, E., Nagura, H. \& Tabayashi, K. Up-regulation of matrix metalloproteinase-2 and membrane-type 1-matrix metalloproteinase were coupled with that of type I procollagen in granulation tissue response after the onset of aortic dissection. Virchows Archiv: an international journal of pathology 448, 811-821, doi:10.1007/s00428-006-0194-5 (2006).

21. Chen, L. et al. A single nucleotide polymorphism in the matrix metalloproteinase 9 gene $(-8202 A / G)$ is associated with thoracic aortic aneurysms and thoracic aortic dissection. The Journal of thoracic and cardiovascular surgery 131, 1045-1052, doi:10.1016/j.jtcvs.2006.01.003 (2006).

22. Kurihara, T. et al. Neutrophil-derived matrix metalloproteinase 9 triggers acute aortic dissection. Circulation 126, 3070-3080, doi:10.1161/circulationaha.112.097097 (2012).

23. Dilme, J. F. et al. Influence of cardiovascular risk factors on levels of matrix metalloproteinases 2 and 9 in human abdominal aortic aneurysms. European journal of vascular and endovascular surgery: the official journal of the European Society for Vascular Surgery 48, 374-381, doi:10.1016/j.ejvs.2014.05.023 (2014).

24. Nagase, H. \& Woessner, J. F., Jr. Matrix metalloproteinases. J Biol Chem 274, 21491-21494 (1999).

25. Aimes, R. T. \& Quigley, J. P. Matrix metalloproteinase-2 is an interstitial collagenase. Inhibitor-free enzyme catalyzes the cleavage of collagen fibrils and soluble native type I collagen generating the specific 3/4- and 1/4-length fragments. J Biol Chem 270, 5872-5876 (1995).

26. Sharma, C. et al. Effect of fluoroquinolones on the expression of matrix metalloproteinase in debrided cornea of rats. Toxicology mechanisms and methods 21, 6-12, doi:10.3109/15376516.2010.529183 (2011).

27. Tsai, W. C. et al. Ciprofloxacin up-regulates tendon cells to express matrix metalloproteinase-2 with degradation of type I collagen. $J$ Orthop Res $29,67-$ 73, doi:10.1002/jor.21196 (2011).

28. Lee, C. C. et al. Risk of Aortic Dissection and Aortic Aneurysm in Patients Taking Oral Fluoroquinolone. JAMA Internal Medicine 175, 1839-1847 (2015).

29. Pasternak, B., Inghammar, M. \& Svanstrom, H. Fluoroquinolone use and risk of aortic aneurysm and dissection: Nationwide cohort study. BMJ (Online) 360 (no pagination) (2018).

30. Daneman, N., Lu, H. \& Redelmeier, D. A. Fluoroquinolones and collagen associated severe adverse events: a longitudinal cohort study. BMJ open 5, e010077 (2015).

31. van der Linden, P. D., Sturkenboom, M. C., Herings, R. M., Leufkens, H. G. \& Stricker, B. H. Fluoroquinolones and risk of Achilles tendon disorders: casecontrol study. Bmj 324, 1306-1307 (2002).

32. Etminan, M., Forooghian, F., Brophy, J. M., Bird, S. T. \& Maberley, D. Oral fluoroquinolones and the risk of retinal detachment. Jama 307, 1414-1419, doi:10.1001/jama.2012.383 (2012).

33. Azhar, B. et al. Misdiagnosis of ruptured abdominal aortic aneurysm: systematic review and meta-analysis. Journal of endovascular therapy: an official journal of the International Society of Endovascular Specialists 21, 568-575, doi:10.1583/13-4626mr.1 (2014).

34. Moher, D., Liberati, A., Tetzlaff, J. \& Altman, D. G. Preferred reporting items for systematic reviews and meta-analyses: the PRISMA statement. International journal of surgery (London, England) 8, 336-341, doi:10.1016/j.jjsu.2010.02.007 (2010).

35. Wells G, S. B., O'Connell D, et al. The Newcastle-Ottawa Scale (NOS) for assessing the quality of nonrandomised studies in meta-analyses, $<$ http://www.ohri.ca/programs/clinical_epidemiology/nosgen.pdf> (

36. Maumus-Robert, S. et al. Short-Term Risk of Aortoiliac Aneurysm or Dissection Associated With Fluoroquinolone Use. J Am Coll Cardiol 73, 875-877, doi:10.1016/j.jacc.2018.12.012 (2019).

37. Lee, C. C. et al. Oral Fluoroquinolone and the Risk of Aortic Dissection. J Am Coll Cardiol 72, 1369-1378, doi:10.1016/j.jacc.2018.06.067 (2018).

38. Meng, L. et al. Assessing fluoroquinolone-associated aortic aneurysm and dissection: Data mining of the public version of the FDA adverse event reporting system. Int J Clin Pract 73, e13331, doi:10.1111/ijcp.13331 (2019).

\section{Figures}



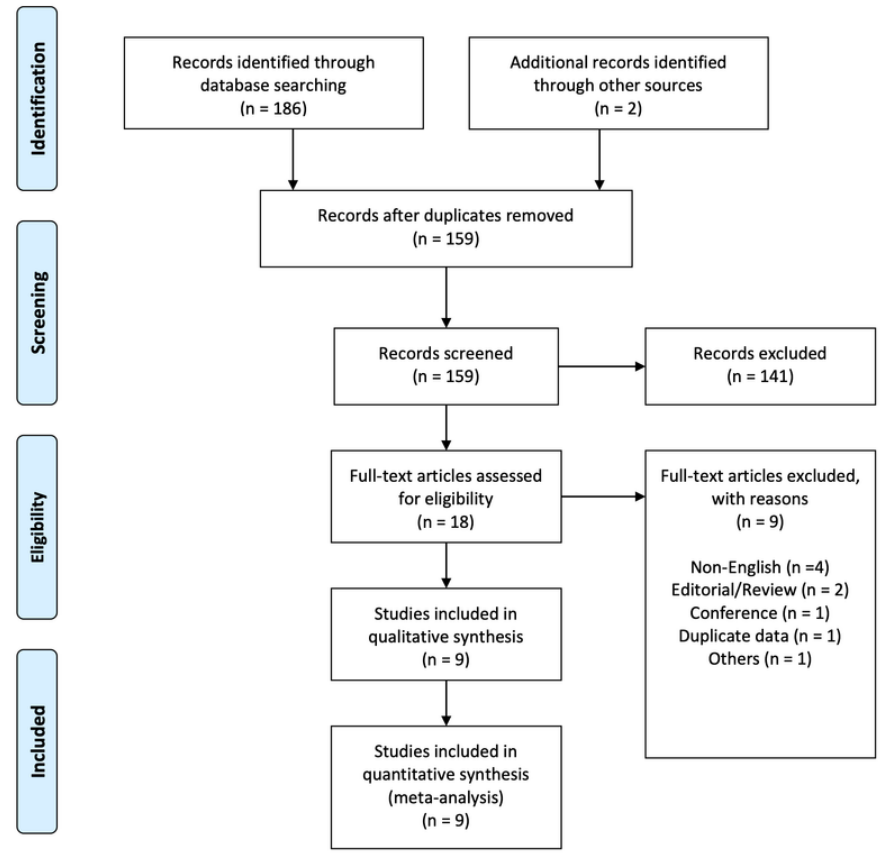

\section{Figure 1}

PRISMA flow diagram

Aortic dissection or ruptured aneurysm

Rate Ratio

Study or Subgroup

log[Rate Ratio]

SE Weight IV, Random, $95 \% \mathrm{Cl}$ Longitudinal cohort / (Nested) case-control studies

Pasternak 2018

Maumus-Robert 2019

Lee 2015

Daneman 2015

Subtotal $(95 \% \mathrm{Cl})$

$\begin{array}{lll}-0.0726 & 0.4598 & 10.1 \%\end{array}$

$0.8948 \quad 0.3188 \quad 17.3 \%$

$0.9361 \quad 0.2435 \quad 23.9 \%$

$1.04720 .1049 \quad 42.2 \%$

$93.4 \%$
$0.93[0.38,2.29]$

$2.45[1.31,4.57]$

$2.55[1.58,4.11]$

$2.85[2.32,3.50]$

$2.38[1.71,3.32]$

Heterogeneity: $\mathrm{Tau}^{2}=0.05 ; \mathrm{Chi}^{2}=5.75, \mathrm{df}=3(\mathrm{P}=0.12) ; \mathrm{I}^{2}=48 \%$

Test for overall effect: $Z=5.11(P<0.00001)$

Pharmacovigilance database analysis (adjusted reporting odds ratios)

Meng 2019

Subtotal $(95 \% \mathrm{Cl})$

0.32930 .5948

$6.6 \%$

$1.39[0.43,4.46]$

Heterogeneity: Not applicable

Test for overall effect: $Z=0.55(P=0.58)$

Total $(95 \% \mathrm{Cl})$

$100.0 \%$

Heterogeneity: $\mathrm{Tau}^{2}=0.05 ; \mathrm{Chi}^{2}=6.91, \mathrm{df}=4(\mathrm{P}=0.14) ; \mathrm{I}^{2}=42 \%$

Test for overall effect: $Z=5.11(P<0.00001)$

Test for subgroup differences: $\mathrm{Chi}^{2}=0.76, \mathrm{df}=1(\mathrm{P}=0.38), \mathrm{I}^{2}=0 \%$

$2.30[1.67,3.17]$
Rate Ratio

IV, Random, $95 \%$ Cl

-


Aortic aneurysm

Rate Ratio

Rate Ratio

Study orSubgroup log[Rate Ratio] SE Weight IV, Random, $95 \% \mathrm{Cl}$ Longitudinal cohort / (Nested) case-control studies

Gopalakrishnan 2020

$0.4667 \quad 0.0812 \quad 29.4 \%$

Pasternak 2018

$\begin{array}{lll}0.6419 & 0.2262 & 13.3 \%\end{array}$

Daneman 2015

$\begin{array}{lll}0.8065 & 0.0527 & 32.8 \%\end{array}$

Lee 2015

$0.8587 \quad 0.1802 \quad 17.3 \%$

$92.8 \%$

Heterogeneity: $\mathrm{Tau}^{2}=0.04 ; \mathrm{Chi}^{2}=13.10, \mathrm{df}=3(\mathrm{P}=0.004) ; \mathrm{I}^{2}=77 \%$

Test for overall effect: $Z=6.01(P<0.00001)$

Pharmacovigilance database analysis (adjusted reporting odds ratios)

$\begin{array}{lllll}\text { Meng } 2019 & 0.7793 & 0.349 & 7.2 \% & 2.18[1.10,4.32]\end{array}$

Subtotal $(95 \% \mathrm{Cl}) \quad 7.2 \% \quad 2.18[1.10,4.32]$

Heterogeneity: Not applicable

Test for overall effect: $Z=2.23(P=0.03)$

Total $(95 \% \mathrm{Cl}) \quad 100.0 \% \quad 2.00[1.63,2.45]$

Heterogeneity: $\mathrm{Tau}^{2}=0.03 ; \mathrm{Chi}^{2}=13.14, \mathrm{df}=4(\mathrm{P}=0.01) ; \mathrm{I}^{2}=70 \%$

Test for overall effect: $Z=6.63(P<0.00001)$

Test for subgroup differences: $\mathrm{Chi}^{2}=0.07, \mathrm{df}=1(P=0.80), \mathrm{I}^{2}=0 \%$

$1.59[1.36,1.87]$

$1.90[1.22,2.96]$

$2.24[2.02,2.48]$

$2.36[1.66,3.36]$

$1.98[1.59,2.48]$

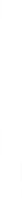
0.2

Favors fluoroquinolone-users

Figure 3

Association between fluoroquinolone use and aortic aneurysm

Aortic aneurysm and/or dissection

Rate Ratio

Rate Ratio

Study or Subgroup

log[Rate Ratio] SE Weight IV, Random, $95 \% \mathrm{Cl}$ IV, Random, $95 \% \mathrm{Cl}$

\begin{tabular}{|c|c|c|c|c|}
\hline \multicolumn{5}{|c|}{ Longitudinal cohort/ (Nested) case-control studies } \\
\hline Dong 2020 & 0.0083 & 0.1055 & $18.0 \%$ & $1.01[0.82,1.24]$ \\
\hline Maumus-Robert 2019 & 0.4235 & 0.1721 & $15.2 \%$ & $1.53[1.09,2.14]$ \\
\hline Gopalakrishnan 2020 & 0.4816 & 0.1002 & $18.2 \%$ & $1.62[1.33,1.97]$ \\
\hline Pasternak 2018 & 0.5068 & 0.2007 & $14.0 \%$ & $1.66[1.12,2.46]$ \\
\hline $\begin{array}{l}\text { Lee } 2015 \\
\text { Subtotal }(95 \% \mathrm{Cl})\end{array}$ & 0.8879 & 0.1447 & $\begin{array}{l}16.4 \% \\
81.9 \%\end{array}$ & $\begin{array}{l}2.43[1.83,3.23] \\
1.57[1.16,2.14]\end{array}$ \\
\hline
\end{tabular}

Pharmacovigilance database analysis (adjusted reporting odds ratios)

Meng 2019

$\begin{array}{llll}0.6649 & 0.3 & 10.1 \% & 1.94[1.08,3.50]\end{array}$

Sommet 2018

$0.7522 \quad 0.3687 \quad 8.0 \%$

$2.12[1.03,4.37]$

Subtotal $(95 \% \mathrm{Cl})$

$18.1 \%$

$2.01[1.28,3.18]$

Heterogeneity: $\mathrm{Tau}^{2}=0.00 ; \mathrm{Chi}^{2}=0.03, \mathrm{df}=1(\mathrm{P}=0.85) ; \mathrm{I}^{2}=0 \%$

Test for overall effect: $Z=3.01(P=0.003)$

Total $(95 \% \mathrm{Cl}) \quad 100.0 \% \quad 1.65[1.26,2.14]$

Heterogeneity: $\mathrm{Tau}^{2}=0.09 ; \mathrm{Chi}^{2}=27.72, \mathrm{df}=6(\mathrm{P}=0.0001) ; \mathrm{I}^{2}=78 \%$

Test for overall effect: $Z=3.70(P=0.0002)$

Test for subgroup differences: $\mathrm{Chi}^{2}=0.77, \mathrm{df}=1(\mathrm{P}=0.38), \mathrm{I}^{2}=0 \%$

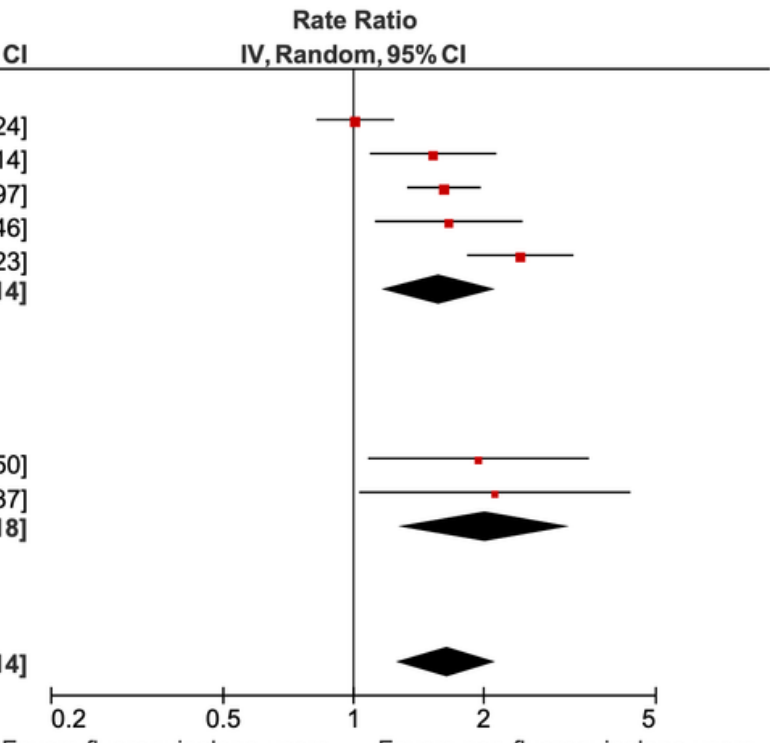

Favors fluoroquinolone-users Favors non-fluoroquinolone users

Figure 4

Association between fluoroquinolone use and aortic dissection or aortic aneurysm

\section{Supplementary Files}

This is a list of supplementary files associated with this preprint. Click to download.

- PRISMA2009checklistfilledFluoro.doc 